\title{
ENERGY-FROM-WASTE IS ESSENTIAL IN MODERN INTEGRATED WASTE MANAGEMENT
}

\author{
Kurt B. Carlsson \\ ABB Environmental Systems AB, Sweden
}

\begin{abstract}
To solve the waste problem and to use the resources in the waste requires an integrated approach.

Each municipality/region/country has its own conditions and an analysis/evaluation of the situation is required.

The combustible part of the domestic waste, which remains after sorting out hazardous and economically valuable material, is a good biofuel. It is locally available for supplying the region with electricity and heat for district heating in the local ecocycle.

Modern waste fired boilers have minimum emissions to air, water and land. In Sweden there are many good examples of efficient energy recovery systems within Integrated Waste Management.
\end{abstract}

\section{KEYWORDS}

Kurt Carlsson; ABB Environmental Systems; Integrated Waste Management; Energy-fromWaste, Emissions, Recycling, Recovery. 


\section{WHAT IS WASTE?}

According to the EU definition waste is "any substance or object in the categories set out in Annex 1 which the holder discards or intends or is required to discard".

Annex 1 is the EU waste list catalogue -94/3/EG from 20 Dec. 1993.

Hazardous waste is listed in the EU directive 94/904/EG of 22 Dec. 1994.

\section{AMOUNTS AND TYPES OF WASTE}

\section{A. Industrial production waste}

\begin{tabular}{|l|c|}
\hline Processes & $\begin{array}{c}\text { Amount } \\
\text { Mtons/year }\end{array}$ \\
\hline From mines & 45 \\
From wood processing & 7 \\
From pulp and paper & 3 \\
From metal processing & 2 \\
From food production & 1 \\
& \\
\hline Total about & 60 \\
\hline
\end{tabular}

Table 1. Waste from industrial production in waste in Sweden 1994 (Ref. 1)
B. Waste collected by the municipalities

\begin{tabular}{|l|c|}
\hline Type of waste & $\begin{array}{c}\text { Amount } \\
\text { Mtons/year }\end{array}$ \\
\hline Household waste & 3.2 \\
Garden waste & 0.1 \\
Ashes etc. & 0.7 \\
Waste water sludge & 1.2 \\
Inorganic waste & 1.0 \\
Industrial waste & 3.0 \\
Demolition etc. waste & 1.5 \\
\hline Total about & 10 \\
\hline
\end{tabular}

Table 2. Municipal solid non hazardous (MSW) in Sweden 1994 (Ref. 1)

\section{WASTE TREATMENT AND UTILISATION IN SWEDEN}

Almost all kinds of waste are a resource and too much of the waste is still placed in landfills. Of the waste treated by the municipalities (1997) about half or 4.3 Mton was placed in landfills, about 0.5 Mton was composted/digested, about 1 Mton was sorted out for material recovery and almost 2 Mton became fuel in heating or combined heat and power stations which then means energy recovery. The amount of hazardous waste from households etc. is estimated to 20000 tons.

For comparison it is interesting to mention that industries generated about 250000 tons of hazardous waste. 
Calculated per person we then get the following table for 1997 (Ref.. 2).

\begin{tabular}{|l|c|}
\hline Waste treatment & $\mathrm{kg} / \mathrm{person}$ \\
\hline Material recovery & 120 \\
Energy recovery & 210 \\
Biological treatment & 60 \\
Placed in landfills & 550 \\
Haz. waste - special treatment & 2.4 \\
\hline
\end{tabular}

Table 3. Treatment of MSW in Sweden 1997 (Ref. 2)

For the future the tendency is clear: less waste to landfill means more waste for material and energy recovery.

Few prognoses count on a real reduction of the amounts of generated waste. The Swedish EPA (Naturvårdsverket) calculates an almost constant amount of household waste and that the amount of waste to landfill shall be reduced by $50-70 \%$ by the year 2005 compared to 1994 .

Further:

Combustible waste should not be landfilled after 2002 .

Organic waste should not be landfilled after 2005.

EU and most of the EU-countries have the same goal in principle, but the timing varies.

\section{INTEGRATED WASTE MANAGEMENT (IWM)}

In the IWM-process waste is a resource, which should be utilised, in the best technical/economical and ecological way.

As each municipality, region, country is unique in many aspects, an analysis of the local situation and the possibilities is always necessary.

Some basic rules apply for all IWM-systems and analyses, e.g.:

Hazardous and hospital waste should be sorted out, kept and treated separately.

The whole waste train should be analysed and evaluated, i.e.

- Generation

- Collection

- Transportation

- Treatment

* Utilisation

- Final disposal

and not only a single stage which may lead to inaccurate conclusions. The main cost in the waste train is often collection/transportation.

Local compost is OK but centralised compost is often a "waste" of energy (Ref. 4).

Most kinds of waste and particularly MSW are a part of the sustainable ecocycle as they mainly contain material from the vegetation.

Look at existing resources for waste utilisation in the municipality or region, e.g. existing digesters at waste water treatment plants.

The cost of landfill will increase considerably with new and stricter demands fees and even stop for organic waste to landfills.

For which material is there a safe market with or without economical incentives? 


\section{ENERGY RECOVERY IN INTEGRATED WASTE MANAGEMENT}

The composition of the municipal solid waste after source separation (Residual Waste or RW) varies, of course, but normally the main part is a contaminated biofuel.

\section{Scenario}

The composition of future municipal solid waste (MSW) (household and similar) for the Stockholm region with a population of 2 million inhabitants is estimated in table 4 with the following result (Ref. 4):

\begin{tabular}{|c|c|c|c|c|c|}
\hline \multirow[b]{3}{*}{ Material } & \multicolumn{3}{|c|}{ Waste data } & \multirow{2}{*}{\multicolumn{2}{|c|}{$\begin{array}{l}\text { Total energy in waste from } \\
2 \text { million people }\end{array}$}} \\
\hline & \multicolumn{2}{|c|}{$\mathrm{kg} /$ inhabitant, year } & \multirow[b]{2}{*}{$\begin{array}{c}\text { Calorific } \\
\text { value } \mathrm{kWh} / \mathrm{kg}\end{array}$} & & \\
\hline & $\begin{array}{l}\text { Before source } \\
\text { separation }\end{array}$ & $\begin{array}{l}\text { After source } \\
\text { separation }\end{array}$ & & $\begin{array}{c}\text { Before source } \\
\text { separation } \\
\text { GWh }\end{array}$ & $\begin{array}{c}\text { After source } \\
\text { separation } \\
\text { GWh }\end{array}$ \\
\hline Hard plastic & 9 & 0 & 11.5 & 207 & 0 \\
\hline Soft plastic & 39 & 39 & 11.5 & 897 & 897 \\
\hline Rubber, leather & 7 & 7 & 9.1 & 127 & 127 \\
\hline Aluminium & 4 & 2.5 & 8.5 & 68 & 43 \\
\hline Liquid board & 10 & 10 & 5.6 & 112 & 112 \\
\hline News, Joumal paper & 54 & 0 & 4.1 & 443 & 0 \\
\hline Other types of paper & 35 & 32 & 4.0 & 280 & 256 \\
\hline $\begin{array}{l}\text { Corrugated } \\
\text { cardboard }\end{array}$ & 12 & 4 & 3.9 & 94 & 31 \\
\hline $\begin{array}{l}\text { Kitchen, garden } \\
\text { waste }\end{array}$ & 108 & 108 & 1.0 & 216 & 216 \\
\hline Very wet waste & 22 & 0 & 0 & 0 & 0 \\
\hline Iron + metals & 10 & 10 & 0 & 0 & 0 \\
\hline Glass & 18 & 9 & 0 & 0 & 0 \\
\hline Others & 7 & 7 & $?$ & $?$ & $?$ \\
\hline Total & 335 & 228.5 & 3.6 & 2444 & 1682 \\
\hline
\end{tabular}

Table 4. Scenario of the future MSW-situation in the Stockholm region with a population of 2 million (Ref. 4).

The calorific value of the MSW after this realistic cost-effective source separation is calculated to about $3.6 \mathrm{KWh} / \mathrm{kg}$, or almost $13 \mathrm{MJ} / \mathrm{kg}$, which is higher than what we have today $-10-11 \mathrm{MJ} / \mathrm{kg}$.

The amount before source separation, $335 \mathrm{~kg} /$ person/year, is less than the actual figure 1998.

In the table we can see that recovery by source separation decreases the available amount of MSW by 212000 tons and the amount of available energy by $762 \mathrm{GWh}$ per year in the region. In (4) it is also estimated that the material recovery by source separation generates an energy gain of somewhere between 280 and $900 \mathrm{GWh}$.

The highest figure ( $900 \mathrm{GWh}$ ) is attained if all wood, which is replaced by recycled paper, could be used as biofuel. In many scenarios the material recovery does not make any gain, but there are losses, which indicate that less source sorting should take place. 
Demolition and industrial waste represent another source of combustible fuel. In the Stockholm region it is estimated (4) that there will be about 90000 ton/year (about 45 $\mathrm{kg} /$ person/year) combustible demolition waste (after source separation) with a calorific value of 4 to $4.5 \mathrm{kWh} / \mathrm{kg}$ and thus a total energy of about $350 \mathrm{GWh} / \mathrm{year}$.

The total amount of industrial waste is estimated to 300000 tons/year of which about 180 000 ton remains as contaminated, mainly biofuel after source separation. This corresponds to $90 \mathrm{~kg}$ combustible waste without ash/person/year. The calorific value of this industrial waste is calculated to about $5 \mathrm{kWh} / \mathrm{kg}$ and the total energy is then about $900 \mathrm{GWh} /$ year.

The available amount of combustible contaminated residual waste - about $80 \%$ biofuel which is estimated to be generated in the Stockholm region, can be summarised in the following table.

\begin{tabular}{|c|c|c|c|c|}
\hline \multirow[t]{2}{*}{ Origin of waste } & \multicolumn{2}{|c|}{ Amount } & \multirow{2}{*}{$\begin{array}{l}\text { Calorific } \\
\text { value } \\
\mathrm{kWh} / \mathrm{kg}\end{array}$} & \multirow{2}{*}{$\begin{array}{c}\text { Total amount of energy in } \\
\text { residual waste in the region } \\
\text { GWh }\end{array}$} \\
\hline & $\begin{array}{l}\text { Specific } \\
\mathrm{kg} / \text { person, } \\
\text { year }\end{array}$ & $\begin{array}{c}\text { Total } \\
\text { ton/year }\end{array}$ & & \\
\hline $\begin{array}{l}\text { Household waste } \\
\text { ca. } 20 \% \text { ash }\end{array}$ & 230 & 460000 & 3.6 & 1700 \\
\hline $\begin{array}{l}\text { Demolition } \\
10 \% \text { ash }\end{array}$ & 50 & 100000 & 3.5 & 350 \\
\hline $\begin{array}{l}\text { Industrial } \\
10 \% \text { ash }\end{array}$ & 100 & 200000 & 4.5 & 900 \\
\hline Total & 380 & 760000 & 3.9 & ca. 3000 \\
\hline
\end{tabular}

Tabl' 5. Estimated combustible waste after source separation in the Stockholm region with a population of 2 million (2 000 000).

These 3000 GWhs correspond to 270000 tons of oil (135 kg/person). By using this contaminated complex combustible waste in combined heat and power stations 150-200 0000 apartments can be supplied with electricity and heat via the district heating network. In the Stockholm region, the district heating network is very large and the heat distribution is no problem.

By using the waste instead of oil/gas/coal in the power stations there will be a reduction of $\mathrm{CO}_{2}$ emissions of about 700000 ton yearly.

The total heat demand in the Stockholm region is 3-4 times what can be generated from own waste and it is therefore realistic to import combustible waste from the area around Stockholm.

There are at least three reasons for this:

There is a heat demand and a sufficient district heating network in the Stockholm region.

The transport cost and energy consumption is low compared to the energy in the waste.

Specific treament cost decreases considerably with the size of plants. 


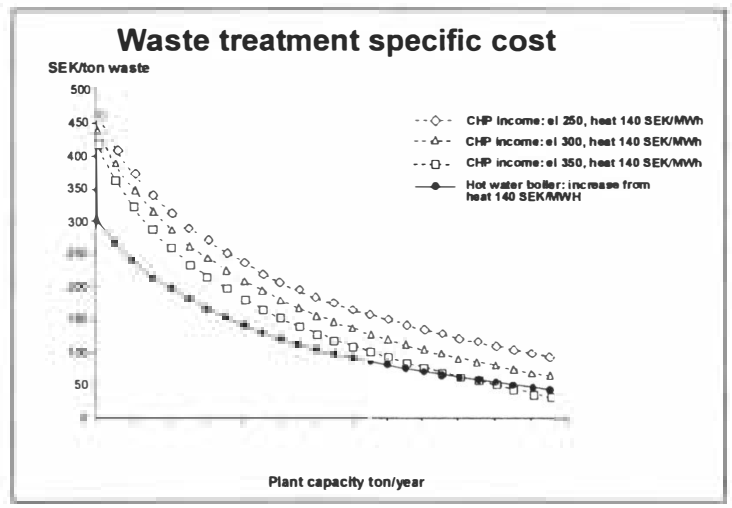

Fig 1. Specific total waste treatment cost in combined heat and power (CHP) and heating plants (Ref. 4).

Combustion with energy recovery is, of course, particularly interesting if most of the generated energy can be used, e.g. steam to industries or to district heating systems. Many of the countries around the Baltic Sea have district heating networks, which can be supplied from waste fired boilers. In some cases also existing boilers can probably be converted for burning waste or waste fractions.

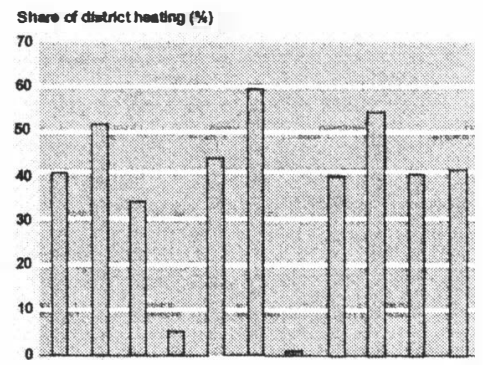

Fig 2. Share of district heating in heat consumption in the residential and service sectors (Ref. 5) 


\section{THE NATURAL AND SUSTAINABLE ECOCYCLE}

The Stockholm Region study (4) shows clearly that a cost-effective waste management system relies on a combination of methods - An Integrated Waste Management System.

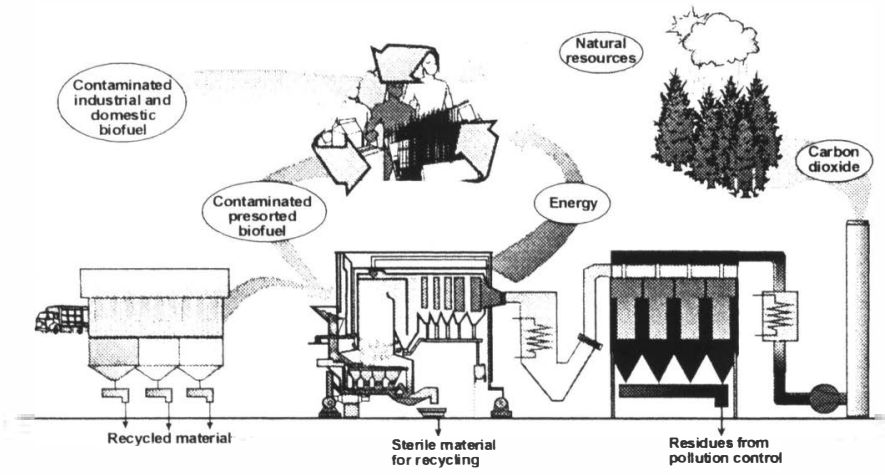

Fig 3. Integrated Waste Management in the natural and sustainable Ecocycle.

Generally, it can be said that highly populated regions in industrial and semi-industrial parts of the world normally require waste fired power stations for a cost-effective waste treatment.

Smaller local waste fired boilers can also be acceptable if the investment and operation cost can be controlled by e.g.

energy delivery from a hot water boiler to a district heating system or steam delivery to the industry

one combustion line - waste is stored from summer to winter in e.g. bales

localisation of the waste fired boiler to a power station area and thus utilisation of common resources.

concentration on one treatment method and utilisation of that method for most of the waste.

\section{EXAMPLES OF ENERGY RECOVERY BY COMBUSTION IN THE ECOCYCLE}

The Stockholm region with a population of 2 million will very much rely on

source sorting of household waste

central sorting/preparation of demolition/industrial waste

very wet waste from markets, shops, restaurants, food industries will be treated anaerobically and the fuel gas - methane and $\mathrm{CO}_{2}-$ will be used in boilers and gas engines.

the main part of the residual waste, about 400000 tons/year, will be fuel in the combined heat and power station Stockholm/Högdalen generating about $200 \mathrm{GWh}$ electricity and $1000 \mathrm{GWh}$ heat for the district heating network.

another 150000 tons of the residual waste are used in the heating stations Södertälje (south of Stockholm) and Bollmora (south-east) generating $450 \mathrm{GWh}$ for mainly district heating. 
The private company Rondeco has built a central composting plant south of Stockholm. In this they will compost wet waste from restaurants, food production plants, sewage sludge and maybe also the wet part of household waste. The goal is to produce compost soil for gardens etc.

\begin{tabular}{|l|c|}
\hline Waste treatment & Amount tons/year \\
\hline$-\quad$ Energy Recovery by Combustion & $500-550000$ \\
$\quad$ Stockholm/Högdalen & \\
Bollmora & \\
$\quad$ Södertälje & 50000 \\
$-\quad$ Composting/Digestion & $150-200000$ \\
\hline$\quad$ Combustible waste to landfill & $700-800000$ \\
\hline Total combustible waste & \\
\hline
\end{tabular}

Table 6. Planned treatment of residual combustible waste in the Stockholm Region with a population of about 2 million.

The Södertälje plant (south of Stockholm) plant is an interesting example of a conversion from fossil fuel to biofuel. The plant was originally built in 1982 with three coal powder fired hot water boilers, each $120 \mathrm{MW}$. One boiler was rebuilt in 1995 to a bubbling fluidised bed for wood chips.

A water-cooled grate was installed in 1998 in boiler No. 1 for burning various demolition and industrial waste but also shredded tyres.

The total cost for the conversion was about SEK $200 \mathrm{M}$ - a new line would have cost at least the double.

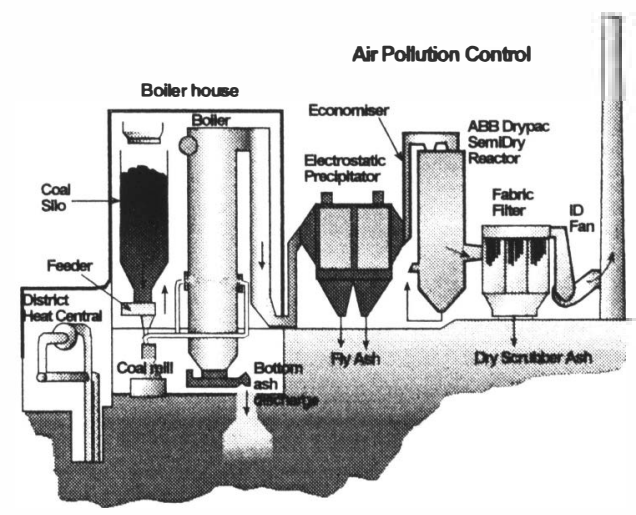

Fig 4. Sketch of the coal powder fired boiler and air pollution control in Södertälje - 120 $M W$. 


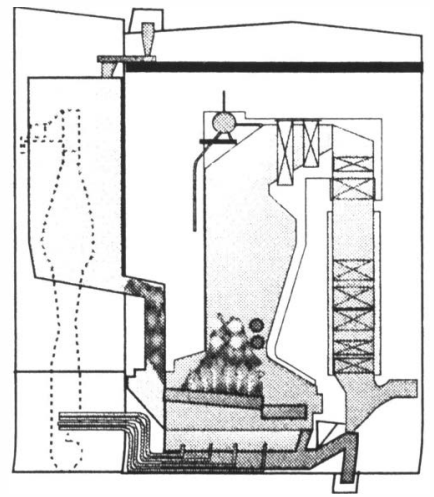

Fig 5. Sketch of the boiler after modification for burning of industrial waste. The power output is reduced by about $20 \%$.

In Sweden there are now 23 plants burning various kinds of waste. Today, five of these burn about $70 \%$ of all waste being burnt in Sweden, all in grate systems. All produce energy for district heating and three of them - Gothenburg, Stockholm and Linköping - also electricity. Linköping has an interesting concept. Three hot water boilers have been converted to produce saturated steam, which is superheated by flue gas from an oil-fired gas turbine. The plant is one of the first of this kind in the world.

The 23 Energy-from-Waste (E-f-W) plants in Sweden show a great variation, there are large plants - small plants grate fired boilers - fluidised beds bubbling as well as circulating steam boilers - hot water boilers plants burning various types of waste, almost only MSW - only industrial waste new plants - old plants

One interesting small plant is the Bollmora plant, south-east of Stockholm. The plant is currently owned and operated by the Swedish state owned power company Vattenfall. The Bollmora $15 \mathrm{MW}$ hot water boiler uses dry waste pellets (RDF) produced by WMI Sellbergs at their plant in Kovik, east of Stockholm and sold to Bollmora for about $100 \mathrm{SEK} / \mathrm{MWh}$ (6). The plant supplying hot water to the local district heating network, is located in the same building as other boilers and in this way common resources can be used.

Another interesting detail for the Bollmora plant is that it is located in the middle of a residential area close to a school. The residents have no complaints whatsoever, they rather like their RDF fired heating station which takes care of their waste in a proper way and delivers hot water back to them at a reasonable price. 


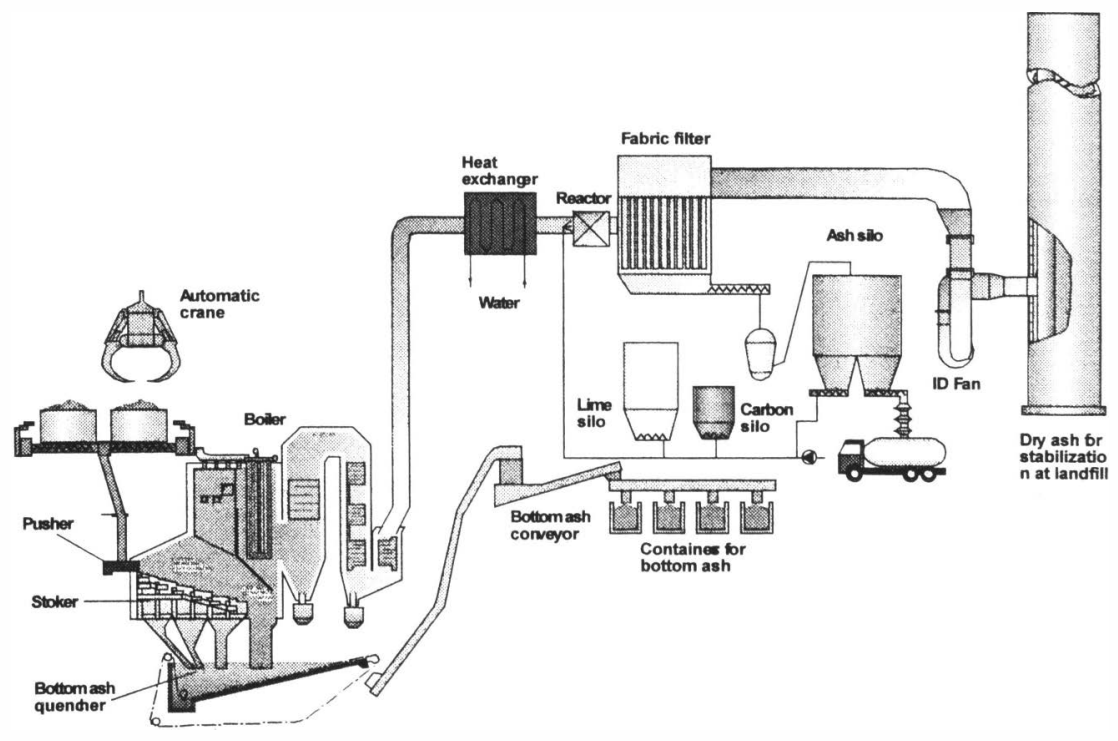

Fig 6. The RDF pellet fired plant in Bollmora, south-east of Stockholm.

The fuel for the plant - RDF pellets - is delivered by normal trucks and stored indoors in bunkers with negative pressure before it is charged to the boiler by an automatic crane. Hydrated lime for the gas cleaning is delivered in closed bulk containers and the ashes from the plant are taken care of by trucks also in closed containers. The ashes are transported to a landfill.

- Bottom ash is used for lining in the landfill

- Fly ash is stabilised before being placed in a special landfill area (monolandfill). All equipment is placed indoors, thus the noise is controlled by insulation and silencers. The plant has normally no waste water.

\section{ENERGY FROM WASTE AS KIDNEY IN SOCIETY}

In the Ecocycle various more or less harmful or even toxic compounds exist as contaminants, or are generated as by-products or by accident.

It is only natural that these unwanted substances are concentrated to waste and waste water. We must therefore have a method to remove them from the circulation and destroy or concentrate them..

By combustion at high temperature, and turbulence, long residence time and excess of oxygen, organic matter will be destroyed. Toxic heavy metals, such as cadmium and mercury are evaporated and concentrated to the fly ash which can be placed in a special landfill with or without pre-treatment. Some heavy metals can sometimes be recovered already today. By 
separate storage they can eventually be reused in the future when the price of the heavy metals has increased.

An economical solution is to co-burn domestic solid waste (MSW + demolition + industrial) with sewage sludge and hospital waste which both contain heavy metals and hundreds (if not thousands) of more or less unknown organic substances.

There are several examples of this cost-effective solution.

Several plants in Sweden also burn hospital waste

Co-combustion of domestic waste and sewage sludge takes place, for instance in the new waste fired combined heat and power station in Brescia, Italy.

\section{Fig 7. Longitudinal sketch of the waste fired combined hed and wer plant in}

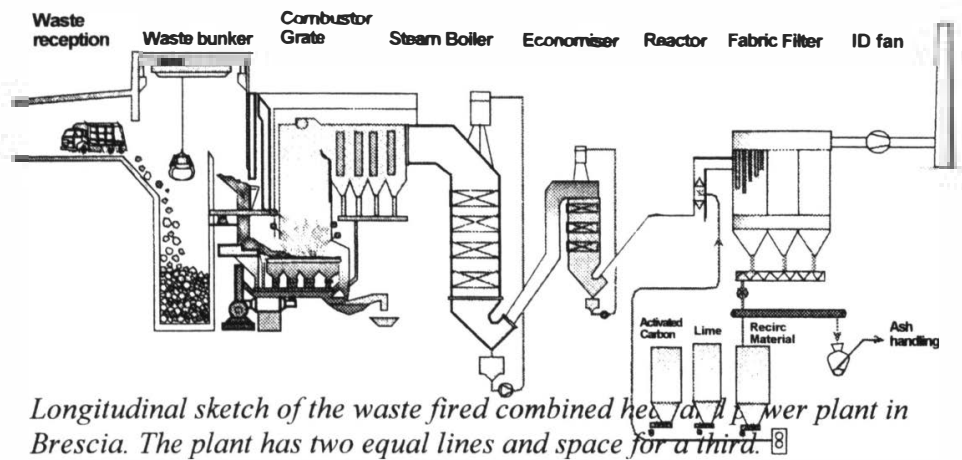

\section{ENVIRONMENTAL CONTROL}

Characteristic of most types of residual domestic combustible waste is that they are mainly biofuels as their origin is from vegetation. By burning they do not increase the $\mathrm{CO}_{2}$ and greenhouse effect. Waste is a renewable resource.

they contain impurities such as

\section{acidifying substances; $\mathrm{S}, \mathrm{Cl}, \mathrm{N}$}

heavy metals

more or less toxic organic compounds

rather much ash - most of this is harmless such as glass.

In the flue gas after the boiler we, therefore, find

- $\mathrm{SO}_{2} ; \mathrm{HCl} ; \mathrm{NO}_{\mathrm{X}}---$

- Metal compounds

- Organic matter, e.g.dioxin in low concentrations

- General fly ash

Of course, the flue gases must be cleaned before being discharged to the atmosphere. 
EU drafts for solid fuels (coal), biomass and waste propose the following emission limits:

\begin{tabular}{|c|c|c|c|c|c|c|}
\hline Fuel & & fuel & & nass & & iste \\
\hline & & $\mathrm{O}_{2}$ & & $\mathrm{O}_{2}$ & $11 \% \mathrm{O}_{2}$ & $6 \% \mathrm{O}_{2}$ \\
\hline $\begin{array}{l}\text { Plant size } \\
\text { MWth }\end{array}$ & $5-100$ & $100-300$ & $5-100$ & $100-300$ & all & all \\
\hline Substance: & & & & & & \\
\hline $\begin{array}{l}\text { Dust } \\
\mathrm{SO}_{2} \\
\mathrm{NO}_{\mathrm{X}}\end{array}$ & $\begin{array}{r}50 \\
850 \\
400\end{array}$ & $\begin{array}{r}30 \\
600-200 \\
200\end{array}$ & $\begin{array}{r}50 \\
600 \\
400\end{array}$ & $\begin{array}{r}30 \\
600-300 \\
300\end{array}$ & $\begin{array}{r}10 \\
50 \\
200\end{array}$ & $\begin{array}{r}16 \\
64 \\
310\end{array}$ \\
\hline $\begin{array}{l}\mathrm{HCl} \\
\mathrm{HF} \\
\mathrm{Hg} \\
\mathrm{Cd} \\
\text { Heavy metals } \\
\text { Dioxin }\end{array}$ & & $\begin{array}{l}\text { No require } \\
\text { "- } \\
\text { "- } \\
\text { "- } \\
\text { ". }\end{array}$ & & & $\begin{array}{l}10 \\
1 \\
0.05 \\
0.05 \\
0.5 \\
0.1\end{array}$ & \\
\hline
\end{tabular}

Table 7. EU draft directives on emission to atmosphere for various boilers. Figures in $\mathrm{mg} / \mathrm{m}^{3} \mathrm{n}$ dry gas $0^{\circ} \mathrm{C}, 101.3 \mathrm{kPa}$, but dioxin in $n g$. (Ref. 7)

As we can see from table 7 , the emission requirements for waste fired boilers are more stringent than for other forms of solid fuels. Besides several more substances are regulated for waste than for other solid fuels (coal, peat, biofuels etc.)

Fortunately, the development of cost-effective pollution control systems has been intensive the last ten years and we have now several proven systems. Also here local conditions are important for the optimal solution and an analysis/evaluation has to be made.

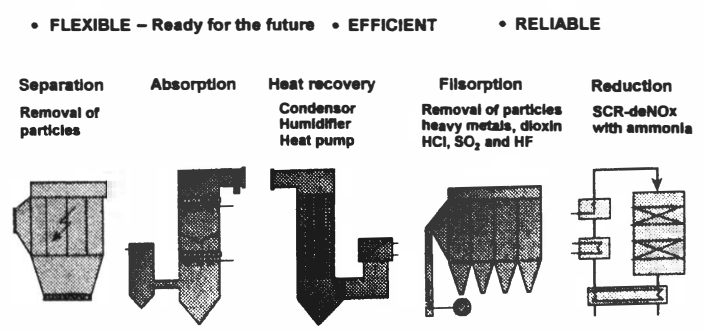

Fig 8. Many APC systems with varying levels of complexity can be built from 5 subssystems. 


\section{AIR POLLUTION CONTROL WITH DRY METHODS}

One example of a cost-effective dry pollution control system is shown in the sketch of the Bollmora plant - fig. 6 and the Brescia plant fig. 7.

The heart of the pollution control is a fabric filter - a big vacuum cleaner -, which is coated with additives to bind gaseous impurities in the gas $-\mathrm{SO}_{2}, \mathrm{HCl}$ and mercury. The filtration of particles - large and small - is very effective in a precoated fabric and very low emissions can be obtained as the following table shows.

\begin{tabular}{|ll|c|c|}
\hline Substance & & $\begin{array}{c}\text { Measured } \\
\text { Emission }\end{array}$ & $\begin{array}{c}\text { EU proposed directive } \\
\text { from Oct. } 1998\end{array}$ \\
\hline $\mathrm{HCl}$ & $\mathrm{mg} / \mathrm{m}^{3} \mathrm{n}$ & 5 & 10 \\
$\mathrm{SO}_{2}$ & $\mathrm{mg} / \mathrm{m}^{3} \mathrm{n}$ & 25 & 50 \\
Dust & $\mathrm{mg} / \mathrm{m}^{3} \mathrm{n}$ & 1 & 10 \\
Mercury & $\mathrm{mg} / \mathrm{m}^{3} \mathrm{n}$ & 0.005 & 0.5 \\
Dioxin & & $<0.01$ & 0.1 \\
TEQ & $\mathrm{ng} / \mathrm{m}^{3} \mathrm{n}$ & & \\
\hline
\end{tabular}

Table 8. Results from guarantee measurements at the Bollmora heating station $m^{3} n=m^{3}$ dry gas $11 \% \mathrm{O}_{2} t=0^{\circ} \mathrm{C}, p=101.3 \mathrm{kPa}$

The pollution control (PC) technology has, of course, been further developed - the PC at Bollmora was started in 1991 and the most modern cost-effective dry pollution control system we have today is the so called NID-system.

In this NID the final cooling of the flue gas takes place in a special duct reactor before the fabric filter. A dust flow - fresh lime and recirculated dust - is humidified and fed into the reactor. When the water is evaporated the flue gas temperature is decreased to an optimal level for the gas cleaning. The water in the dust also catalyses the absorption and the reaction between the hydrated lime and $\mathrm{HCl}, \mathrm{SO}_{2}$ etc.

The $\mathrm{NO}_{\mathrm{X}}$ reduction is normally done in a cost-effective way by the so called selective non catalytic deNO $\mathrm{N}_{X}$ method (SNCR).

The principle is to let the nitrogen oxides $\left(\mathrm{NO}_{\mathrm{X}}\right)$, generated by the combustion, react with ammonia $\left(\mathrm{NH}_{3}\right)$ forming a harmless nitrogen gas $\left(\mathrm{N}_{2}\right)$. 


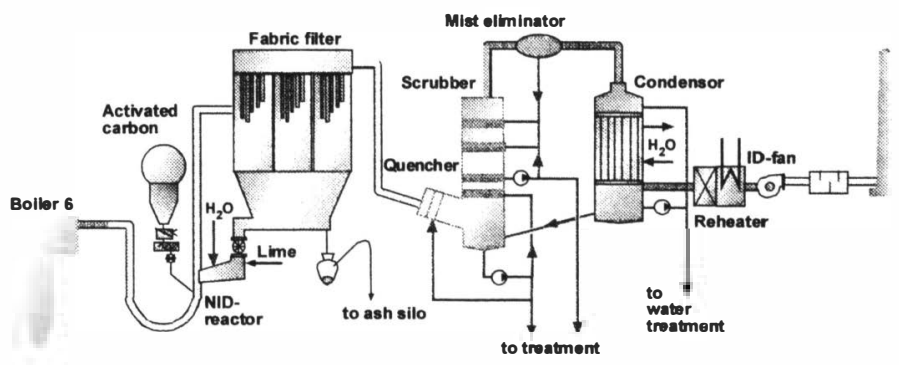

Fig 9. Flue gas cleaning by the NID-method followed by a wet system for final pollution control and heat recovery by condensation for the new waste fired boiler No. 6 in Stockholm/Högdalen.

\section{AIR POLLUTION CONTROL WITH WET METHODS}

As said before most of the inorganic impurities in the waste are evaporated during the effective combustion and the organic matter is destroyed.

The air pollution control installation removes the impurities and the flue gas emitted to the atmosphere is clean.

However, as we cannot destroy elements, we will find them and their compounds in the residues - in dry systems in the ashes. Hydrochloric acid and its reaction products are all very water-soluble and therefore give some difficulties in the ash handling.

In a wet air pollution control system, the hydrochloric acid is absorbed in the washing water and, after water treatment, discharged to a suitable recipient, a big river/lake or the sea.

An interesting example of a cost-effective pollution control system with a wet scrubber was install

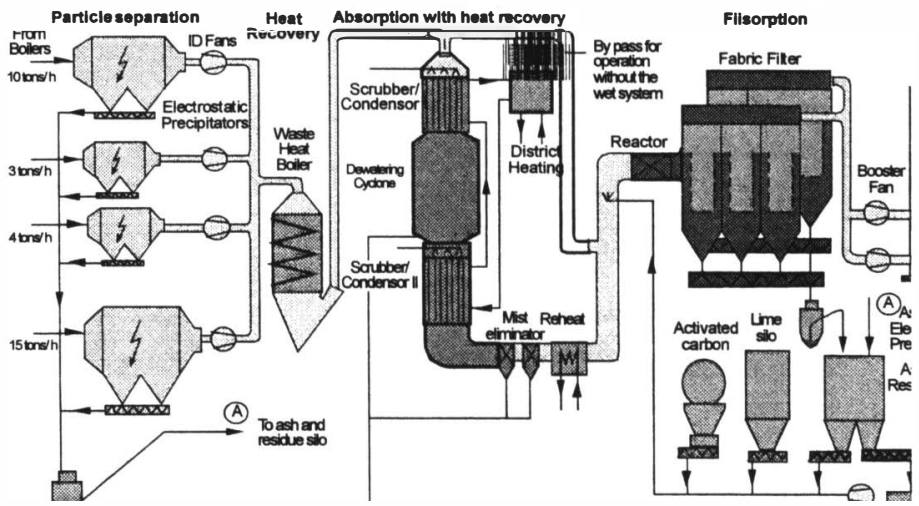

Fig 10. Uppsala, Sweden. A plant with a capacity of 240000 tons per year and a combination of wet scrubber and heat recovery by means of condensation. 


\begin{tabular}{|c|c|c|c|c|c|}
\hline \multirow[t]{3}{*}{ Component } & \multicolumn{5}{|c|}{ Concentrations in $\mathrm{mg} /{ }^{3} \mathrm{n}$ dry gas but dioxins in $\mathrm{ng} / \mathrm{m}^{3} \mathrm{n}$ dry gas } \\
\hline & \multicolumn{2}{|c|}{$\begin{array}{l}\text { Measured emissions } \\
\text { from Guarantee tests }\end{array}$} & \multirow{2}{*}{$\begin{array}{c}\begin{array}{c}\text { Guaranteed } \\
\text { Emission }\end{array} \\
10 \% \mathrm{CO}_{2}\end{array}$} & \multirow{2}{*}{$\begin{array}{c}\text { Swedish } \\
\text { Regulation } \\
10 \% \mathrm{CO}_{2}\end{array}$} & \multirow{2}{*}{$\begin{array}{c}\begin{array}{c}\text { German } \\
\text { Regulation }\end{array} \\
11 \% \mathrm{CO}_{2}\end{array}$} \\
\hline & $\begin{array}{c}\text { Scrubber in } \\
\text { by-pass } \\
10 \% \mathrm{CO}_{2}\end{array}$ & $\begin{array}{c}\text { Total APC in } \\
\text { operation } \\
10 \% \mathrm{CO}_{2}\end{array}$ & & & \\
\hline Dust & $<1$ & 1 & 10 & 20 & 10 \\
\hline $\mathrm{HCl}$ & $<15$ & $<1$ & 30 & 100 & 10 \\
\hline $\mathrm{HF}$ & $<0.1$ & $<0.1$ & 50 & 0.03 & 1 \\
\hline $\mathrm{SO}_{2}$ & $<20$ & $<15$ & 0.03 & 0.1 & 50 \\
\hline $\mathrm{Cd}+\mathrm{TI}$ & - & $<0.001$ & 0.1 & & 0.05 \\
\hline $\mathrm{Hg}$ tot & $<0.01$ & 0.005 & & & 0.05 \\
\hline $\mathrm{HM}$ & - & $<0.05$ & & & 0.5 \\
\hline TEQ Dioxin & $<0.05$ & $<0.05$ & & & 0.1 \\
\hline
\end{tabular}

Remarks: 1) TEQ Dioxin acc. to Eadon, German regulations acc. to I-TEQ.

2) $\mathrm{HM}=$ Heavy metals.

Table 9. Results of performance measurements in Uppsala.

\section{RESIDUE TREATMENT}

As for other fuels most of the impurities in the waste are converted to the flue gas and then, via air pollution control, to the residues.

In some cases, it is possible to recover valuable elements, e.g. zinc or to reuse the residues as a neutralisation or stabilisation agent. So for example the Norwegian hazardous waste company Noah uses ashes for the neutralisation of waste sulphuric acid.

However, the most common method is to dispose it to a landfill directly or after treatment:

- Directly in a controlled, special monolandfill or a landfill for hazardous waste.

- After solidification/stabilisation

- solidification with cement or similar

- stabilisation with chemicals

- solidification/stabilisation with other residues

- combinations

\section{ENVIRONMENTAL IMPACTS}

Waste is normally not clean - the residual waste after sorting and separation is contaminated and not suitable for material recycling nor composting, but as it mainly is a contaminated biofuel, it is very suitable to use it for energy recovery in, preferably, local heating or combined heat and power stations.

Old Energy-from-Waste installations were more destruction plants with no or very little environmental control.

New and modernised plants with emissions according to the proposed EU-directive (table 7) or better has so low emissions that their impact on the environment is negligible (Ref. 8). 
Compared with all emissions of various substances in Sweden, the $23 \mathrm{~W}-\mathrm{t}-\mathrm{E}$ plants contribute to a very minor part, besides from dioxin and mercury where the contribution is $5-10 \%$.

After the start-up of the final APC stage (pre-coated fabric filter à la Uppsala) at the Renova E-f-W plant in Gothenburg, the dioxin emission will be reduced to the half and the contribution from all E-f-W will be less than $5 \%$.

\section{CONCLUSION}

The solution of our waste problem is a combination of methods, which have to be analysed and evaluated for each municipality/region/country.

After sorting out hazardous material and objects for reuse and material recycling, e.g. aluminium and sometimes glass and paper, the rest is a good fuel, a biofuel which can replace fossil fuels in local heating, combined heat and power stations, or in boilers for supplying industries with e.g. steam.

The environmental impact of the modern E-f-W plants is negligible and, compared with other methods - composting, further sorting and landfill - often much lower.

The costs for an optimised modern E-f-W plant must not be higher than for a modern similar plant for biofuel.

The capital cost is a large part of the total, but can be reduced by e.g. rebuilding of an existing coal fired plant.

Sweden is a very interesting country to study in respect of cost-effective, reliable and environmentally friendly Energy-from-Waste plants.

\section{REFERENCES}

1. SCB: Miljösverige $3^{\text {rd }}$ edition 1997 (data from "Naturmiljön i siffror 1996")

2. RVF: Swedish Waste Management 1998

3. Waste Management - The Swedish Experience Ministry of ForeignAffairs and the Swedish Environmental Protection Agency, Article No. UD 98.091. Printed 1999.

4. Björn Dahlroth: Avfall och Energi. En kunskapssammanställning StorStockholms Energi Stockholm 1998.

5. Baltic 21 - Energy

Baltic 21 Series No. 3/98

Danish Energy Agency Copenhagen

Fax +4533114743

6. Personal contact 990617

7. M.C. Kalf Kema NL: Environmental impact of energy production Comparison between different energy sources. Conference RAI Amsterdam: The future of Waste to Energy 26/5 1999. 
8. The Swedish translation of an article originally published in the German journal Abfallwirtschafts-Joumal 5 (1993) No. 3.

Läkarföreningens vetenskapliga rådgivande kommitté: Potentiella hälsorisker från avfallsförbränningsanläggningar". 